\title{
Nurses' Practices towards Prevention and Control of Nosocomial Infections in Madonna University Teaching Hospital Elele Rivers State
}

\author{
Folorunso Dipo Omisakin*
}

Department of Medical-Surgical Nursing, Faculty of Nursing, College of Health Sciences, Niger Delta University, Wilberforce Island, Bayelsa State, Nigeria.
"Correspondence:

Dipo Omisakin F, Department of Medical-Surgical Nursing, Faculty of Nursing, College of Health Sciences, Niger Delta University, Nigeria, Tel: 08037254715; E-mail: omifod@yahoo. co.uk.

Received: 04 March 2018; Accepted: 27 March 2018

Citation: Folorunso Dipo Omisakin. Nurses' Practices towards Prevention and Control of Nosocomial Infections in Madonna University Teaching Hospital Elele Rivers State. Nur Primary Care. 2018; 2(2): 1-7.

\section{ABSTRACT}

Nurses have the obligation to protect patients against nosocomial infection especially those who have undergone surgery and are immune compromised. Therefore nurses should have good practices of adherence to infection prevention and control standard precautions in order to ensure delivery of quality of care. This study examined nurses 'practices towards prevention and control of nosocomial infection in Madonna University Teaching Hospital, Elele, Rivers State. A descriptive research design was utilized to answer the research questions. All ninety-seven (97) nurses currently working in Madonna University teaching Hospital formed the population for this study. The sample size was calculated using the formula $\left(n=N / 1+N(e)^{2}\right)$. A simple random sampling technique was employed to select from duty roster a sample size of 78 nurses across all the units of hospital. Data was collected through a specially designed questionnaire that was derived from other published studies dealing with the same topic. The Statistical Package for Social Sciences (SPSS-20) was used for data processing. Simple descriptive statistics (percentages and frequency) and inferential statistic (Chi square) were used. The institution's ethical committee approval was obtained. Ethical considerations in the conduct of research were followed to prevent ethical dilemmas. Most of the nurses in the current study have good practice regarding infection control standard precautions. However, a few of the nurses had poor practices in the maintenance of the patient's care environment, this signal to a need for further educational intervention in form of seminars and workshops. Provision of guidelines on infection control to enhance good practice may improve patients' outcomes and consequently enhance quality of provided nursing care.

Keywords

Surgical patients, Nosocomial infection, Infection control measures, Role of nurses.

\section{Introduction}

Nosocomial, Hospital acquired or Healthcare-associated infections (HAI) are defined as infections not present and without evidence of incubation at the time of admission to a healthcare setting. As a better reflection of the diverse healthcare settings currently available to patients, the term healthcare-associated infections replaced old ones such as nosocomial, hospital-acquired or hospitalonset infections [1]. Within hours after admission, a patient's flora begins to acquire characteristics of the surrounding bacterial pool. Most infections that become clinically evident after 48 hours of hospitalization are considered hospital-acquired. Infections that occur after the patient is discharged from the hospital can be considered health-care associated if the organisms were acquired during hospital stay [2]. Nosocomial infections (NI) accounts for higher rates of morbidity and mortality among critically ill patients, due to severity of illness and thus increased susceptibility to acquire more micro-organism related to their presence especially in the surgical wards. Nosocomial infections have been recognized as a problem affecting the quality of health care and a principal source of adverse healthcare outcomes in the setting of study. It pose serious threat to hospital admissions and those who work or dwell around hospital premises and often increase costs of health care both for patients and the health services. It has been documented in the literature that these infections have serious impacts such as increased hospital stay days, increased costs of healthcare, economic hardship to patients and their families 
and even deaths, are among the many negative outcomes [3]. It constitutes a global health problem, and is considered as one of the leading causes of increased morbidity and mortality; longer duration of hospital; increased severity of the underlying illness; increased utilization of devices for monitoring and treatment; increased cost of treatment in both developed and resource-poor countries; and impairment of the quality of patient's and family's life [4]. Nosocomial infections remain a major unwanted side effect of healthcare, often causing serious harm to patients. Despite availability of effective precautions and evidence based guidelines, the practices of healthcare workers nurses in particular resulting in these measures being applied insufficiently.

Infection control and prevention refer to the clinical application of microbiology in practice. It is also a quality standard which is essential for the well-being and safety of patients, staff and visitors in hospitals' environment. It encompasses the processes and activities which identify and reduce the risks of acquiring and transmitting endemic or epidemic infections among individuals [5]. Infection control and prevention is the responsibility of critical care nurses, and represents an integral element of patients' safety programmes [6]. Nurses have a professional and moral obligation to protect the health of their patients and share the responsibility to sustain and protect the natural environment for achieving quality nursing care and clarifying nursing's contribution to improve health care outcomes and patient experiences [7]. Practices of nurses should be assessed in order to develop interventions aimed at improving adherence to infection control measures.

Surgical patients are at high risk of developing life threatening problems as infection; most of nurses providing care for those patients have low level of practice especially application of infection control measures. However, there is evidence that management and care of surgical patients requires a unique body of knowledge and skills from a range of multidisciplinary team members especially the nurse, and encompasses a wide variety of roles and responsibilities, mainly prevention of infection. With reports of low compliance, cases of multi-drug resistance infections and poor awareness of NIs, a study on knowledge, attitude and practice of nosocomial infections prevention is long overdue in an environment like ours in which personal and organizational attitudes towards interventions such as hand washing, cost containment and logistical barriers may be described as still existing. Therefore, the objective of this study was to examine nurses' practices towards prevention and control of nosocomial infections in Madonna University Teaching Hospital, Elele, Rivers State.

\section{Materials and Methods}

Research Design

This study employed a descriptive survey design to examine nurses' practices towards prevention and control of nosocomial infections in Madonna University Teaching Hospital, Elele, Rivers State. The study was conducted from March to June 2016. The Madonna University Teaching Hospital serves as a general/referral center for adults and children in Elele and its environs. It's bounded by Umuadwo to the North, Isiokpo to the east, Ahoda to the south and Omoku to the west. The town indigenous ethnic groups are the Ikwere people. The hospital was founded by very Reverend Father Emmanuel Mathew Paul Edeh (CSSP) (OFR) in 2002. Madonna University Teaching Hospital has a working capacity of hundred one and two (102) nurses. The hospital is made up of subunits such as; medical ward, surgical ward, pediatrics unit, outpatient department, casualty, psychiatric, theatre obstetrics and gynecology unit, and the maternity including the antenatal unit, postnatal unit. This setting serves as a teaching hospital where patients with various disease conditions are admitted for treatment on regular bases. It is also a training institution for healthcare professionals.

\section{Sample and Sampling techniques}

All ninety-seven (97) nurses currently working in Madonna University teaching Hospital (MUTH) formed the population for this study. All the nurses were invited to participate in the study. The sample size was calculated using the formula $(n=N / 1+N(e) 2$ . A simple random sampling technique was employed to select from duty roster 78 nurses across all the units of hospital.

\section{Instrument for Data Collection}

The data of this study was collected through a specially designed questionnaire that was derived from other published studies dealing with the same topic. The questionnaire comprised of two sections namely: Section A, focuses on the sociodemographic characteristics of the participants; and Section B, examines participant's practices toward prevention and control of nosocomial infections. Nurses' socio-demographic characteristic as regards their age, gender, marital status, Nursing Qualification, Department of work, Working experience, and attendance of infection control training course. Nurse's practice was assessed by statements using a 5-item Likert scale (ranging from always 5 to never, 1$)$. The practice scores were categorized into good $(\geq 80 \%)$, fair $(59-79 \%)$, and poor $(\leq 59 \%)$.

\section{Validity and Reliability of the Instrument}

The researchers ensure face and content validity, which is the degree to which the items in an instrument adequately represent the universe of the content. The questionnaire was reviewed by a group of nurse educators who are experts in the field of study. This group did not participate in the main study. The reviewers supported the assertion that the components of the questionnaire accurately reflected the phenomenon being studied. A pilot study was carried out on 20 nurses (not included in the final study). A coefficient of 0.86 was gotten which shows that the instrument was reliable. This study was to test the clarity, applicability of the study tool, and identify the difficulties that may be faced during the application. Also, the time needed for filling the questionnaire by the staff was estimated during this pilot study. The necessary modifications were made accordingly.

\section{Method of Data Collection}

The nurses were approached during their leisure period and the researcher administered the questionnaire. Aside from the written 
consent, verbal consent of the nurses was obtained prior to the administration of the questionnaire. Once the respondents are done with the questionnaire, the researchers have them collected immediately.

\section{Method of Data Analysis}

The Statistical Package for Social Sciences (SPSS-20) was used for data processing. Simple descriptive statistics (percentages and frequency) and inferential statistic (Chi square) was used.

\section{Ethical Considerations}

The institution's ethical committee approval was sought. Ethical considerations in the conduct of research were followed to prevent ethical dilemmas. To ensure confidentiality and anonymity, neither the name of respondents nor that of the units/wards involved was requested on the questionnaires. No physical or psychological risks were involved. The list of participants for sampling purposes is kept safe to ensure confidentiality and anonymity (Brink, 2003). Approval by the Nursing Department of Madonna University, Elele Rivers State was obtained. Consent from the respondents was secured as well. Several strategies were utilized to protect the nurse's rights who agreed to participate in this study. The nurses were informed of the purpose of the study, and that they have the right to refuse to participate. Also the voluntary nature of participation is stressed as well as confidentiality. Furthermore, the nurses were told that they can refrain from answering any questions and they can terminate at any time.

\section{Results}

The data analysis was guided by the research questions for this study. The data were presented using frequency tables, and percentages. Majority (37.2\%) of the respondents were between the ages 30 to 39 years, while $(29.5 \%)$ were between $20-29$ years of age, majority $(76.9 \%)$ were females, $(23.1 \%)$ males. $37.2 \%$ of the respondent belong to nursing officer I cadre, principal nursing officer $(25.6 \%)$, nursing officer II $(21.8 \%)$, while assistant chief nursing officer and chief nursing officer were $11.5 \%$ and $3.9 \%$ respectively. Majority of the respondent $(35.90 \%)$ had $1-5$ years of working experience, (28.20\%) had 6-10 years, and (25.64\%) had 16 and above years of working experience (Table 1). Overwhelming majority of the respondents: Always washes hands after touching blood, secretions, excretions, and contaminated items, whether or not gloves are worn $(97.4 \%)$, immediately after gloves are removed $(92.3 \%)$, before patient contact $(80.8 \%)$, and after patient contact $(88.5 \%)$. Uses a plain soap for routine hand washing $(92.3 \%)$, an antimicrobial agent for specific circumstances $(89.7 \%)$, and ensures availability of hand-washing facilities with clean running water (89.7\%) always (Table 2); always wears gloves when touching blood, body fluids, secretions, excretions, and contaminated items (89.7\%); puts on clean gloves just before touching mucous membranes $(93.6 \%)$; puts on clean gloves just before touching non-intact skin $(89.7 \%)$; changes gloves between tasks and procedures on the same patient after contact with potentially infectious material $(80.8 \%)$; and removes gloves after use, before touching non-contaminated items and surfaces, and before going to another patient (88.5\%) (Table 3); always wears mask when attending patients with communicable respiratory infections (92.3\%); wears mask during procedures that are likely to generate splashes or sprays of blood, body fluids, secretions, and excretions $(82.1 \%)$; and wears eye protection or a face shield during procedures that are likely to generate splashes or sprays of blood, body fluids, secretions, and excretions (78.2\%) (Table 4); always wears a gown to protect skin and prevent soiling of clothing during procedures and patient-care activities that are likely to generate splashes or sprays of blood, body fluids, secretions, or excretions (87.2\%); removes soiled gown as soon as possible, and performs hand hygiene $(92.3 \%)$; ensures that reusable equipment is not used for the care of another patient until it has been cleaned and reprocessed appropriately $(89.7 \%)$; handles equipment soiled with blood, body fluids, secretions, and excretions in a manner that prevents skin and mucous membrane exposures, contamination of clothing, and transfer of pathogens to other patients (93.6\%); and (93.6\%) always cleans, disinfects, and reprocess reusable equipment appropriately before use with another patient (Tables 5).

Also, almost all the respondents always: ensures that the hospital has adequate facilities for procedures for the routine care, cleaning, and disinfection of environmental surfaces (92.3\%); handles used linen, soiled with blood, body fluids, secretions, and excretions in a manner that prevents skin and mucous membrane exposures $(92.3 \%)$; handles used linen in a manner that avoids transfer of microorganisms to other patients and environments $(89.7 \%)$; takes care to prevent injuries when using needles, scalpels, and other sharp instruments or devices (93.6\%); and uses ventilation devices as an alternative to mouth-to-mouth resuscitation methods $(92.3 \%)$, and $(93.6 \%)$ always takes care when disposing of used needles $(92.3 \%)$, and when cleaning used instruments (Table 6). Overwhelming majority of the respondents always: Places a patient who contaminates the environment or who does not assist in maintaining appropriate hygiene in an isolated (or separate) room $(89.7 \%)$; places acute febrile respiratory symptomatic patients at least 1 metre ( $3 \mathrm{ft})$ away from others in common waiting areas $(84.6 \%)$; posts visual alerts at the entrance to health-care facilities instructing persons with respiratory symptoms to practice respiratory hygiene/cough etiquette $(89.7 \%)$; considers making hand hygiene resources, tissues and masks available in common areas and areas used for the evaluation of patients with respiratory illnesses (93.6\%); and educates health workers, patients, and visitors on respiratory hygiene and cough etiquette $(88.5 \%)$ (Table 7). Majority $(59.00 \%)$ of the respondents had good practices towards prevention and control of nosocomial infections, while $28.20 \%$ had fair and $12.80 \%$ poor (Table 8 ).

Testing of hypothesis revealed that calculated $\chi^{2}$ value is 7.026, which is greater than table $\chi^{2}$ value is 0.1026 at 0.05 level of significance. This result is unlikely to occur if there is no association between years of experience and nurse's practices towards prevention and control of nosocomial infections. Thus, it was conclude that there appears to be an association between years of experience and nurses' practices towards prevention and control of nosocomial infections in Madonna University Teaching Hospital, Elele, Rivers State. 


\begin{tabular}{|c|l|c|c|}
\hline \multicolumn{2}{|l|}{ Variables } & Frequency (n) & Percentage (\%) \\
\hline \multirow{4}{*}{ Age (years) } & $20-29$ & 23 & 29.5 \\
\cline { 2 - 4 } & $30-39$ & 29 & 37.2 \\
\cline { 2 - 4 } & $40-49$ & 20 & 25.6 \\
\cline { 2 - 4 } & 50 and above & 06 & 07.7 \\
\hline \multirow{4}{*}{ Gender } & Male & 18 & 23.1 \\
\cline { 2 - 4 } & Female & 60 & 76.9 \\
\hline \multirow{4}{*}{\begin{tabular}{c} 
status \\
\cline { 2 - 4 }
\end{tabular}} & Nursing officer II & 17 & 21.8 \\
\cline { 2 - 4 } & Nursing officer I & 29 & 37.2 \\
\cline { 2 - 4 } & Principal nursing officer & 20 & 25.6 \\
\cline { 2 - 4 } & Ass. Chief nursing officer & 09 & 11.5 \\
\cline { 2 - 4 } & Chief nursing officer & 03 & 03.9 \\
\hline \multirow{3}{*}{\begin{tabular}{c} 
Expears of \\
\cline { 2 - 4 }
\end{tabular}} & $1-5$ & 28 & 35.9 \\
\cline { 2 - 4 } & $6-10$ & 22 & 28.2 \\
\cline { 2 - 4 } & $11-15$ & 08 & 10.3 \\
\cline { 2 - 4 } & 16 and above & 20 & 25.6 \\
\hline
\end{tabular}

Table 1: Socio-Demographic Characteristics of Respondents.

\begin{tabular}{|c|l|c|c|}
\hline \multicolumn{2}{|c|}{ Items } & $\begin{array}{c}\text { Frequency } \\
\text { (n) }\end{array}$ & $\begin{array}{c}\text { Percentages } \\
\text { (\%) }\end{array}$ \\
\hline \multicolumn{2}{|c|}{ Hand Washing and Hand Hygiene } \\
\hline $\begin{array}{c}\text { Washes hands after touching } \\
\text { blood, secretions, excretions, and } \\
\text { contaminated items, whether or not } \\
\text { gloves are worn. }\end{array}$ & Always & 76 & 97.4 \\
\cline { 2 - 4 } $\begin{array}{c}\text { Washes hands immediately after } \\
\text { gloves are removed }\end{array}$ & Often & 02 & 02.6 \\
\cline { 2 - 4 } & Always & 72 & 92.3 \\
\hline \multirow{2}{*}{$\begin{array}{c}\text { Washes hands immediately before } \\
\text { patient contact }\end{array}$} & Often & 06 & 07.7 \\
\cline { 2 - 4 } & Olways & 63 & 80.8 \\
\cline { 2 - 4 } & Often & 12 & 15.4 \\
\hline \multirow{2}{*}{$\begin{array}{c}\text { Washes hands immediately after } \\
\text { patient contact }\end{array}$} & Sometimes & 03 & 03.8 \\
\cline { 2 - 4 } & Always & 69 & 88.5 \\
\cline { 2 - 4 } & Often & 06 & 07.7 \\
\hline \multirow{2}{*}{$\begin{array}{c}\text { Uses a plain soap for routine hand } \\
\text { washing }\end{array}$} & Sometimes & 03 & 03.8 \\
\cline { 2 - 4 } & Always & 72 & 92.3 \\
\hline \multirow{2}{*}{$\begin{array}{c}\text { Uses an antimicrobial agent for } \\
\text { specific circumstances }\end{array}$} & Often & 06 & 07.7 \\
\cline { 2 - 4 } & Always & 70 & 89.7 \\
\hline \multirow{2}{*}{$\begin{array}{c}\text { Ensures availability of hand-washing } \\
\text { facilities with clean running water }\end{array}$} & Often & 08 & 10.3 \\
\cline { 2 - 4 } & Always & 70 & 89.7 \\
\cline { 2 - 4 } & Often & 06 & 07.7 \\
\hline
\end{tabular}

Table 2: Hand Washing and Hand Hygiene.

\begin{tabular}{|c|c|c|c|}
\hline \multicolumn{2}{|c|}{ Gloving } & $\begin{array}{c}\text { Frequency } \\
\text { (n) }\end{array}$ & $\begin{array}{c}\text { Percentages } \\
\text { (\%) }\end{array}$ \\
\hline $\begin{array}{c}\text { Wears gloves when touching blood, } \\
\text { body fluids, secretions, excretions, and } \\
\text { contaminated items }\end{array}$ & Always & 70 & 89.7 \\
\cline { 2 - 4 } & Often & 08 & 10.3 \\
\hline \multirow{2}{*}{$\begin{array}{c}\text { Puts on clean gloves just before touching } \\
\text { mucous membranes }\end{array}$} & Always & 73 & 93.6 \\
\cline { 2 - 4 } & Often & 05 & 06.4 \\
\hline \multirow{2}{*}{$\begin{array}{c}\text { Puts on clean gloves just before touching } \\
\text { non-intact skin }\end{array}$} & Always & 70 & 89.7 \\
\cline { 2 - 4 } & Often & 08 & 10.3 \\
\hline
\end{tabular}

Nur Primary Care, 2018

\begin{tabular}{|c|c|c|c|}
\hline $\begin{array}{c}\text { Changes gloves between tasks and } \\
\text { procedures on the same patient after } \\
\text { contact with potentially infectious } \\
\text { material }\end{array}$ & Always & 63 & 80.8 \\
\cline { 2 - 4 } & Often & 15 & 19.2 \\
\hline $\begin{array}{c}\text { Removes gloves after use, before } \\
\text { touching non-contaminated items and } \\
\text { surfaces, and before going to another } \\
\text { patient }\end{array}$ & Always & 69 & 88.5 \\
\cline { 2 - 4 } & Often & 09 & 11.5 \\
\hline
\end{tabular}

Table 3: Gloving.

\begin{tabular}{|c|c|c|c|}
\hline \multicolumn{2}{|c|}{ Mask, Eye Protection, and Face Shield } & $\begin{array}{c}\text { Frequency } \\
\text { (n) }\end{array}$ & $\begin{array}{c}\text { Percentages } \\
\text { (\%) }\end{array}$ \\
\hline $\begin{array}{c}\text { Wears mask during procedures that are } \\
\text { likely to generate splashes or sprays } \\
\text { of blood, body fluids, secretions, and } \\
\text { excretions }\end{array}$ & Always & 64 & 82.1 \\
\cline { 2 - 4 } & Often & 14 & 17.9 \\
\hline $\begin{array}{c}\text { Wears mask when attending patients with } \\
\text { communicable respiratory infections }\end{array}$ & Always & 72 & 92.3 \\
\cline { 2 - 4 } & Often & 06 & 07.7 \\
\hline $\begin{array}{c}\text { Wears eye protection or a face shield } \\
\text { during procedures that are likely to } \\
\text { generate splashes or sprays of blood, } \\
\text { body fluids, secretions, and excretions }\end{array}$ & Always & 61 & 78.2 \\
\cline { 2 - 4 } & Often & 17 & 21.8 \\
\hline
\end{tabular}

Table 4: Mask, Eye Protection, and Face Shield.

\begin{tabular}{|c|c|c|c|}
\hline \multicolumn{2}{|c|}{ Gowning and Patient-care equipment } & \multirow{2}{*}{$\begin{array}{c}\begin{array}{c}\text { Frequency } \\
\text { (n) }\end{array} \\
68 \\
68\end{array}$} & \multirow{2}{*}{$\begin{array}{c}\begin{array}{c}\text { Percentages } \\
(\%)\end{array} \\
87.2\end{array}$} \\
\hline $\begin{array}{l}\text { Wears a gown to protect skin and } \\
\text { prevent soiling of clothing during } \\
\text { procedures and patient-care activities }\end{array}$ & Always & & \\
\hline $\begin{array}{c}\text { sprays of blood, body fluids, secretions, } \\
\text { or excretions }\end{array}$ & Often & 10 & 12.8 \\
\hline \multirow{2}{*}{$\begin{array}{l}\text { Removes soiled gown as soon as } \\
\text { possible, and performs hand hygiene }\end{array}$} & Always & 72 & 92.3 \\
\hline & Often & 06 & 07.7 \\
\hline \multirow{2}{*}{$\begin{array}{l}\text { Ensures that reusable equipment is not } \\
\text { used for the care of another patient until } \\
\text { it has been cleaned and reprocessed } \\
\text { appropriately }\end{array}$} & Always & 70 & 89.7 \\
\hline & Often & 08 & 10.3 \\
\hline \multirow{2}{*}{$\begin{array}{l}\text { Handles equipment soiled with } \\
\text { blood, body fluids, secretions, and } \\
\text { excretions in a manner that prevents } \\
\text { skin and mucous membrane exposures, } \\
\text { contamination of clothing, and transfer } \\
\text { of pathogens to other patients }\end{array}$} & Always & 73 & 93.6 \\
\hline & Often & 05 & 06.4 \\
\hline \multirow{2}{*}{$\begin{array}{c}\text { Cleans, disinfects, and reprocess } \\
\text { reusable equipment appropriately } \\
\text { before use with another patient }\end{array}$} & Always & 75 & 93.6 \\
\hline & Often & 03 & 06.4 \\
\hline
\end{tabular}

Table 5: Gowning and Patient-care equipment.

\begin{tabular}{|c|c|c|c|}
\hline \multicolumn{2}{|c|}{ Items } & $\begin{array}{c}\text { Frequency } \\
\text { (n) }\end{array}$ & $\begin{array}{c}\text { Percentages } \\
\text { (\%) }\end{array}$ \\
\hline $\begin{array}{c}\text { Ensures that the hospital has adequate } \\
\text { procedures for the routine care, cleaning, } \\
\text { and disinfection of environmental } \\
\text { surfaces }\end{array}$ & Always & 72 & 92.3 \\
\cline { 3 - 4 } & Linen & 06 & 07.7 \\
\hline $\begin{array}{c}\text { Handles used linen, soiled with blood, } \\
\text { body fluids, secretions, and excretions in } \\
\text { a manner that prevents skin and mucous } \\
\text { membrane exposures }\end{array}$ & Always & 72 & 92.3 \\
\cline { 2 - 4 } & Often & 06 & 07.7 \\
\hline $\begin{array}{c}\text { Handles used linen in a manner that } \\
\text { avoids transfer of microorganisms to other } \\
\text { patients and environments }\end{array}$ & Always & 70 & 89.7 \\
\cline { 2 - 4 } & Often & 08 & 10.3 \\
\hline
\end{tabular}

Volume 2 | Issue 2 | 4 of 7 


\begin{tabular}{|c|c|c|c|}
\hline Occupational Health and Blood-borne \\
$\begin{array}{c}\text { Pathogens Takes care to prevent injuries } \\
\text { when using needles, scalpels, and othe } \\
\text { sharp instruments or devices }\end{array}$ & Always & 73 & 93.6 \\
\cline { 2 - 4 } & Often & 05 & 06.4 \\
\hline $\begin{array}{c}\text { Uses ventilation devices as an alternative } \\
\text { to mouth-to- mouth resuscitation methods }\end{array}$ & Always & 72 & 92.3 \\
\cline { 2 - 4 } & Often & 06 & 07.7 \\
\hline \multirow{2}{*}{ Uses care when disposing of used needles } & Always & 72 & 92.3 \\
\cline { 2 - 4 } & Often & 06 & 07.7 \\
\hline \multirow{2}{*}{ Uses care when cleaning used instruments } & Always & 73 & 93.6 \\
\cline { 2 - 4 } & Often & 05 & 06.4 \\
\hline
\end{tabular}

Table 6: Environmental Control, linen handling.

\begin{tabular}{|c|c|c|c|}
\hline \multicolumn{2}{|c|}{ Patient's Care Environment } & $\begin{array}{c}\text { Frequency } \\
\text { (n) }\end{array}$ & $\begin{array}{c}\text { Percentages } \\
\text { (\%) }\end{array}$ \\
\hline $\begin{array}{c}\text { Places a patient who contaminates the } \\
\text { environment or who does not assist in } \\
\text { maintaining appropriate hygiene in an } \\
\text { isolated (or separate) room }\end{array}$ & Always & 70 & 89.7 \\
\cline { 3 - 4 } $\begin{array}{c}\text { Places acute febrile respiratory } \\
\text { symptomatic patients at least 1 metre } \\
\text { (3ft) away from others in common } \\
\text { waiting areas }\end{array}$ & Often & 08 & 10.3 \\
\cline { 3 - 4 } & Always & 66 & 84.6 \\
\hline $\begin{array}{c}\text { Posts visual alerts at the entrance } \\
\text { to health-care facilities instructing } \\
\text { persons with respiratory symptoms } \\
\text { to practice respiratory hygiene/cough } \\
\text { etiquette }\end{array}$ & Always & 70 & 89.7 \\
\cline { 2 - 4 } & Often & 08 & 10.3 \\
\hline $\begin{array}{c}\text { Considers making hand hygiene } \\
\text { resources, tissues and masks available } \\
\text { in common areas and areas used } \\
\text { for the evaluation of patients with } \\
\text { respiratory illnesses }\end{array}$ & Always & 73 & 93.6 \\
\cline { 2 - 4 } & Often & 05 & 06.4 \\
\hline $\begin{array}{c}\text { Educates health workers, patients, } \\
\text { and visitors on respiratory hygiene } \\
\text { and cough etiquette }\end{array}$ & Always & 69 & 88.5 \\
\cline { 2 - 4 } & Often & 09 & 11.5 \\
\hline
\end{tabular}

Table 7: Place of Care of the Patient.

\begin{tabular}{|c|c|c|c|}
\hline Level of practice & Score Points & Frequency (n) & Percentages (\%) \\
\hline Good & $\geq 80 \%$ & 46 & 59.0 \\
\hline Fair & $59-79 \%$ & 22 & 28.2 \\
\hline Poor & $\leq 59 \%$ & 10 & 12.8 \\
\hline
\end{tabular}

Table 8: level of Nurse's Practices towards Prevention and Control of Nosocomial Infections.

The highest score obtainable for the 33 items on nurse's practice is $33 \times 5$ $=165$ always; lowest possible score $33 \times 1=33$ never.

\begin{tabular}{|c|c|c|c|c|}
\hline & \multicolumn{3}{|c|}{ Nurse's practices } & \multirow{2}{*}{ Total } \\
\cline { 1 - 4 } Years of experience & Good & Fair & Poor & \\
\hline $1-5$ & 16 & 8 & 4 & 28 \\
\hline $6-10$ & 10 & 8 & 4 & 22 \\
\hline $11-15$ & 4 & 2 & 2 & 08 \\
\hline 16 and above & 16 & 4 & 0 & 20 \\
\hline Total & 46 & 22 & 10 & 78 \\
\hline
\end{tabular}

Table 9: Association between nurse's practices towards prevention and control of nosocomial infections and their years of experience. The formula for calculating Chi square $\left(\chi^{2}\right)$ is $\Sigma(\mathrm{Oi}-\mathrm{Ei})^{2} / \mathrm{Ei}$.

Where: $\mathrm{Oi}=$ the observed frequency in the ith cell of the table; $\mathrm{E} i=$ the expected frequency in the ith cell of the table.

\section{Discussion of Findings}

Hospital acquired infection is a common problem all over the world demanding for up to date knowledge and refined practical nursing skills that can play important roles in preventing infection. Nurses should have the opportunity to practice infection control on a day-to-day basis as an integral part of patients' care [8].

\section{Demographic Data of the Respondents}

A sample size of 78 nurses participated in this study. Majority $(37.2 \%)$ of the respondents were between the ages 30 to 39years; $76.9 \%$ were females; $37.2 \%$ of the respondent belong to nursing officer I cadre, principal nursing officer $(25.6 \%)$, nursing officer II $(21.8 \%)$, while assistant chief nursing officer and chief nursing officer were $11.5 \%$ and $3.9 \%$ respectively; and $35.90 \%$ had $1-5$ years of working experience, $(28.20 \%)$ had 6-10 years, $(25.64 \%)$ had 16 and above years of working experience. This finding is in concordance with previous studies $[9,10]$.

\section{Nurses' Practices of Universal Infection Control Measures}

Nurses' practices regarding infection control and standard precautions in the current study demonstrates that, about two third of the studied sample had good practice which was found to be higher than what was reported in $[11,12]$.

Nurses are the health care professionals have the obligation to protect critically ill patients against infection especially those who are immune compromised, in order to enhance their recovery, prevent deterioration in their health, and achieve high quality nursing care. Therefore nurses should have sound knowledge and strict adherence to infection control standard precautions. Overwhelming majority of the respondents; always washes hands after touching blood, secretions, excretions, and contaminated items, whether or not gloves are worn (97.4\%), immediately after gloves are removed $(92.3 \%)$, before patient contact $(80.8 \%)$, and after patient contact $(88.5 \%)$. Uses a plain soap for routine hand washing $(92.3 \%)$, an antimicrobial agent for specific circumstances $(89.7 \%)$, and ensures availability of hand-washing facilities with clean running water $(89.7 \%)$ always.

Overwhelming majority of the respondents: always wears mask when attending patients with communicable respiratory infections (92.3\%); wears mask during procedures that are likely to generate splashes or sprays of blood, body fluids, secretions, and excretions (82.1\%); and wears eye protection or a face shield during procedures that are likely to generate splashes or sprays of blood, body fluids, secretions, and excretions (78.2\%). Also, overwhelming majority of the respondents always: wears a gown to protect skin and prevent soiling of clothing during procedures and patient-care activities that are likely to generate splashes or sprays of blood, body fluids, secretions, or excretions (87.2\%); removes soiled gown as soon as possible, and performs hand hygiene $(92.3 \%)$; ensures that reusable equipment is not used for the care of another patient until it has been cleaned and reprocessed appropriately (89.7\%); handles equipment soiled with blood, body 
fluids, secretions, and excretions in a manner that prevents skin and mucous membrane exposures, contamination of clothing, and transfer of pathogens to other patients (93.6\%); and cleans, disinfects, and reprocess reusable equipment appropriately before use with another patient (93.6\%).

Findings of this study was similar to that of [8], who noticed, satisfactory knowledge regarding: standard precautions; transmission of blood borne diseases; and methods used to prevent infection such as rules of eating and drinking in the intensive care unit; and immunization against disease among majority of their studied sample.

Nurses' Practices of maintenance of the Patient's Care Environment The behaviors of health care providers and their interactions with the health care system influence the rate of nosocomial infections. Physicians and nurses have the unique opportunity to directly reduce nosocomial infections through recognizing and applying evidence-based procedures to prevent infections among patients and protecting the health of the staffs. Almost all the respondents always: ensures that the hospital has adequate facilities and procedures for the routine care, cleaning, and disinfection of environmental surfaces (92.3\%); handles used linen, soiled with blood, body fluids, secretions, and excretions in a manner that prevents skin and mucous membrane exposures (92.3\%); handles used linen in a manner that avoids transfer of microorganisms to other patients and environments $(89.7 \%)$; takes care to prevent injuries when using needles, scalpels, and other sharp instruments or devices (93.6\%); and uses ventilation devices as an alternative to mouth-to-mouth resuscitation methods $(92.3 \%)$, care when disposing of used needles $(92.3 \%)$, and care when cleaning used instruments (93.6\%).

Overwhelming majority of the respondents always: places a patient who contaminates the environment or who does not assist in maintaining appropriate hygiene in an isolated (or separate) room (89.7\%); places acute febrile respiratory symptomatic patients at least 1 metre ( $3 \mathrm{ft}$ ) away from others in common waiting areas $(84.6 \%)$; posts visual alerts at the entrance to healthcare facilities instructing persons with respiratory symptoms to practice respiratory hygiene/cough etiquette $(89.7 \%)$; considers making hand hygiene resources, tissues and masks available in common areas and areas used for the evaluation of patients with respiratory illnesses (93.6\%); and educates health workers, patients, and visitors on respiratory hygiene and cough etiquette $(88.5 \%)$. However, only a few of the nurse had poor practices in the maintenance of the patient's care environment.

The findings of this study revealed an association between years of experience and nurse's practices towards prevention and control of nosocomial infections in Madonna University Teaching Hospital, Elele, Rivers State. This was unlike the findings of Fashafsheh, Ayed, Eqtait and Harazneh [14], who reported no relationship between knowledge or practice regarding infection control and age, years of experience, and training course of their studied group and Alnoumas, Fayda, Enezi, Isaeed, Makboul and El-Shazly
[14], that primary health care workers showed good knowledge and positive attitude, but poor practice regarding control measures against Hospital Acquired infections.

\section{Conclusion}

In conclusion, most of the nurses in the current study have good practice regarding infection control standard precautions. However, a few of the nurse had poor practices in the maintenance of the patient's care environment, this signal to a need for further educational intervention in form of seminars and workshops. Improving practice of nurses through continuing in-service educational programs; emphasizing the importance of following latest evidence-based practices of infection control in continuing education / training program; providing training programs for newly nurses about infection control and at regular intervals; and a replication of this study using observation checklist should be done in a wider setting covering more than one institution.

Provision of nursing guidelines according to study results to enhance good practice may improve patients' outcomes and consequently enhance quality of nursing care.

\section{References}

1. Barclay L. Healthcare-acquired infections fall in critically ill kids. Medscape Medical News. September. 2014.

2. Patrick S, Kawai A, Kleinman K. Health care-associated infections among critically ill children in the US. Pediatrics. 2014; 134: 705-712.

3. Kaye K, Anderson JD, Sioanne R, et al. The impact of surgical site infection on older patients. J. Am Geriatr Soc. 2009; 57: 46-54.

4. Uwaezuoke SN, Obu HA. Nosocomial infections in neonatal intensive care units cost-effective control strategies in resource-limited countries. Nigerian journal of paediatrics. 2013; 40: 125-132.

5. David OM, Famurewa O. Towards effective management of nosocomial infections in Nigerian hospitals- a review. Academic Arena. 2010; 2.

6. Royal College of Nursing. Essential practice for infection prevention and control Guidance for nursing staff, London: RCN. 2012; Publication code: 004166.

7. Currie L, Lecko C, Gallagher R, et al. Safety principle of nursing practice C Nursing Standard. 2011; 25: 35-37.

8. Eskander HG, Morsy WY, Elfeky HA. Intensive Care Nurses Knowledge Practices regarding Infection Control Standard Precautions at a Selected Egyptian Cancer Hospital. Journal of Education and Practice. 2013; 4: 160-174.

9. Sreedharan J, Muttappillymyalil J, Venkatramana M. et al. Knowledge about standard precautions among university hospital nurses in the United Arab Emirates. East Mediterranean Health Journal. 2011; 17: 331-334.

10. Efstathiou G, Papastavrou E, Raftopoulos V, et al. Compliance of Cypriot nurses with Standard Precautions to avoid exposure to pathogens. Nursing and Health Sciences. 2011; 13: 53-59.

11. Agaral M, Thomas P. Knowledge and Practice of Nursing 
Staff towards Infection Control Measures in the Palestinian Hospitals. Journal of Education and Practice. 2015; 6: 79-90.

12. Talaat E, Shamia E. Developing a control action plan for infection prevention at the endoscopy unit. Journal of international Academic research. 2011; 2: 412-420.

13. Fashafsheh I, Ayed A, Eqtait F, et al. Knowledge and Practice of Nursing Staff towards Infection Control Measures in the
Palestinian Hospitals. Journal of Education and Practice. 2015; 6: 79-90.

14. Alnoumas SR, Enezi FA, Isaeed MA, et al. Knowledge attitude and behavior of primary health care workers regarding health care-associated infections in Kuwait. Greener Journal of Medical Sciences. 2012; 2: 092-098. 